\title{
Evidence of the Presence of Thyroid Hormones in Achatina fulica Snails
}

\author{
DANILO LUSTRINO ${ }^{1, *}$, ALBA C.M. SILVA ${ }^{1}$, IRACEMA G. ARAUJO ${ }^{1}$, VICTOR M. \\ TUNHOLI ${ }^{1}$, VINÍCIUS M. TUNHOLI-ALVES ${ }^{1}$, ROSANE N. CASTRO ${ }^{2}$, DENISE \\ P. CARVALHO ${ }^{3}$, JAIRO PINHEIRO ${ }^{1}$ and MICHELLE P. MARASSI ${ }^{1}$
}

\begin{abstract}
${ }^{1}$ Departamento de Ciências Fisiológicas, Instituto de Ciências Biológicas e da Saúde, Campus da Universidade Federal Rural do Rio de Janeiro, s/n, Rodovia BR-465, 23897-000 Seropédica, RJ, Brazil

${ }^{2}$ Departamento de Química, Instituto de Ciências Exatas, Campus da Universidade Federal Rural do Rio de Janeiro, s/n, Rodovia BR-465, 23897-000 Seropédica, RJ, Brazil ${ }^{3}$ Instituto de Biofísica Carlos Chagas Filho, Universidade Federal do Rio de Janeiro, Av. Carlos Chagas Filho, 373, CCS-Bloco G, Cidade Universitária, Ilha do Fundão, 21941-902 Rio de Janeiro, RJ, Brazil
\end{abstract}

Manuscript received on October 14, 2016; accepted for publication on January 3, 2017

\begin{abstract}
The objective of this study was to identify thyroid hormones and to examine their putative site of synthesis in Achatina fulica snails. For this purpose, radioimmunoassays were performed for $\mathrm{T}_{3}$ and $\mathrm{T}_{4}$ before and after long starvation with or without hemolymph deproteinization. Sodium/iodide symporter activity in vivo was analyzed through ${ }^{125} \mathrm{I}$ administration with and without $\mathrm{KClO}_{4}$ pretreatment. Only $\mathrm{T}_{4}$ was detected, and its concentration decreased due to starvation or deproteinization. However, high-performance liquid chromatography analysis also showed the presence of $\mathrm{T}_{2}$ and $\mathrm{T}_{3}$ apart from $\mathrm{T}_{4}$, but $\mathrm{rT}_{3}$ was not detected in the A. fulica hemolymph. The sodium/iodide symporter activity was greater in cerebral ganglia than digestive gland, but $\mathrm{KClO}_{4}$ treatment did not inhibit iodide uptake in any of the tissues analyzed. Altogether, our data confirm for the first time the presence of thyroid hormones in A. fulica snails and suggest their participation in the metabolism control in this species, although the putative site of hormone biosynthesis remains to be elucidated.
\end{abstract}

Key words: Achatina fulica, Sodium/iodine symport, Thyroid hormones, Thyroglobulin.

\section{INTRODUCTION}

In mammals, the thyroid gland is responsible for the biosynthesis and secretion of 3,3',5,5'-tetraiodo-1-thyronine 1-thyroxine $\left(1-\mathrm{T}_{4}\right)$ and

Correspondence to: Danilo Lustrino

E-mail: danilolustrino@gmail.com

*Present address: Departamento de Fisiologia, Instituto de Ciências Biológicas e da Saúde, Universidade Federal de Sergipe, Campus Prof. José Aloísio de Campos, s/n, Sala 23, 49100-000 São Cristóvão, SE, Brazil 3,3',5-triiodo-1-thyronine (1-T 3 ), so-called thyroid hormones (THs). The biosynthesis of $\mathrm{T}_{3}$ and $\mathrm{T}_{4}$ occurs through several steps that are dependent on thyroglobulin (TG) synthesis, iodide transport across basal membrane (by $\mathrm{Na}^{+} / \mathrm{I}^{-}$symporter, NIS), iodide oxidation, tyrosyl iodination sites in TG and coupling of the iodotyrosines, a process catalyzed by the enzyme thyroperoxidase (TPO) (Larsen et al. 1998). So, TG protein is endocyted by the apical 
membrane of the follicular cell, and once inside the phagolysosome it is degraded to release $\mathrm{T}_{3}$ and $\mathrm{T}_{4}$ into the bloodstream. In the circulation, THs play an important role in the regulation of energy homeostasis by stimulating oxygen consumption and heat generation. They are also important to the normal growth and development of the organism (Haber et al. 1988, Gupta and Chakrabarty 1990).

THs and their receptors have been well studied in vertebrates, but less is known about the mechanisms by which they regulate the physiology and behavior in mollusks. Tensen et al. (1994) showed the presence of thyroid-stimulating hormone $(\mathrm{TSH})$ receptors in the freshwater gastropod Lymnaea stagnalis and Heyland et al. (2006) showed evidence of the endogenous synthesis of THs in the sea hare Aplysia californica, and of the gene that encodes a peroxidase (AcaTPO) that is similar to the TPO found in mammals. More recently, Huang et al. (2015) demonstrated that THs are produced in the Pacific oyster, Crassostrea gigas. However, to our knowledge the presence of THs and the mechanisms of regulation and synthesis/metabolism of THs in land snails are still poorly unknown.

The terrestrial snail Achatina fulica, known as the giant African snail, is considered an agricultural pest and intermediate host of different parasites (Thiengo et al. 2007). These characteristics along with its rapid dissemination on the American continents have drawn attention to developing strategies for control of this invasive snail. Since many behavioral and physiological processes in mollusks are regulated by hormones, including growth and reproduction (Gomot et al. 1992, Gonzalez et al. 1995, Gooding and LeBlanc 2004), knowledge about endocrine aspects in A. fulica can support strategies for its control. Thus, the aim of the present study was to identify the presence of THs in A fulica snails (under basal and starvation conditions) using radioimmunoassay and highperformance liquid chromatography (HPLC) analysis. Furthermore, NIS activity was evaluated to try to identify the production site of these hormones.

\section{MATERIALS AND METHODS}

Achatina fulica COLLECTION AND MAINTENANCE

Specimens of A. fulica were collected manually early on summer mornings from residential gardens located in Seropédica, Rio de Janeiro state $\left(22^{\circ} 46^{\prime}\right.$ 59" $\mathrm{S}$ and $43^{\circ} 40^{\prime} 45^{\prime \prime} \mathrm{W}, 33 \mathrm{~m}$ height). The snails were maintained under laboratory conditions in transparent plastic boxes $(50 \times 30 \times 15 \mathrm{~cm})$ with a $3 \mathrm{~cm}$ layer of moistened earth at the bottom. The animals were fed with lettuce leaves ad libitum and the food was renewed on alternate days. The mollusks were submitted to an acclimation period of three weeks to the laboratory conditions before starting the experiments $\left(26 \pm 2^{\circ} \mathrm{C}\right)$.

To identify the presence of $\mathrm{T}_{4}$ and $\mathrm{T}_{3}$ hormones in hemolymph of A. fulica snails, two groups were formed: Control group $(n=10)$ that was fed as described above throughout experimental period and Starvation $(\mathrm{n}=10)$, a group of snails that were left without food for four weeks (Rudolph and Bailey 1985). So, the specimens from each group were randomly chosen, dissected by removing their shell and then, the hemolymph $(\sim 2 \mathrm{~mL})$ was collected with the aid of a syringe by heart puncture and stored in microtubes at $-10^{\circ} \mathrm{C}$ until utilization. Samples were maintained in an ice bath during the dissections. To assess whether THs could be bound to hemolymph proteins, the same hemolymph samples were submitted to deproteinization protocol (Nelson 1944), thus two new subgroups were formed: No changes $(n=10)$, with normal hemolymph and Deproteinized $(\mathrm{n}=10)$, in which the hemolymph was deproteinized.

Furthermore, to correlate TH concentrations with the biomass of animals, the new group of snails $(n=7)$ under basal condition was used. For that, the snails were individually weighed using 
a digital analytical balance and body size was measured by using a metric ruler when the snails were resting and so, hemolymph was collected as described above.

The protocol studies followed the international guidelines and standards for the ethical use of animals in research and agree with Ethical Principles in Animal Research adopted in Brazil.

RADIOIMMUNOASSAY (RIA) FOR TOTAL T AND T $_{3}$

Circulating $\mathrm{T}_{3}$ and $\mathrm{T}_{4}$ levels were determined by specific coated-tube RIA kits: $\mathrm{T}_{3}, 3100$ Active; and $\mathrm{T}_{4}, 3200$ Active (Diagnostic System Laboratory, Webster, TX). Hormone-stripped rat serum was used for the standard curves of total $\mathrm{T}_{4}$, and $\mathrm{T}_{3} . \mathrm{T}_{3}$ assay sensitivity was of $0.1 \mathrm{nmol} / \mathrm{L}$, and inter- and intra-assay coefficients of variation varied from 8.3 to $8.6 \%$ and from 2.9 to $3.3 \%$, respectively. $\mathrm{T}_{4}$ assay sensitivity was $13 \mathrm{nmol} / \mathrm{L}$ and inter- and intraassay coefficients of variation varied from 5.6 to $8.6 \%$ and 4 to $5.1 \%$, respectively. All procedures were performed following the recommendations of the kit.

\section{HPLC ANALYSIS}

For this assay, we adapted the technique from Alexander and Nishimoto (1979), de la Vieja et al. (1997), Gika et al. (2005). Briefly, the reagents 3,3',5,5'-tetra-iodo-1-thyronine 1-thyroxine (1$\mathrm{T}_{4}$ ), 3,3',5-triiodo-1-thyronine (1- $\left.\mathrm{T}_{3}\right)$, reverse 3,3',5'-triiodo-L-thyronine ( $\mathrm{rT}_{3}$ ) and 3,5-diiodo-1thyronine $\left(1-\mathrm{T}_{2}\right)$ were used, obtained from SigmaAldrich (Steinheim, Germany). Standard solutions of the compounds were prepared at a concentration of $2 \mathrm{mg} / \mathrm{mL}$ in a mixture of $\mathrm{MeOH}$ and $0.01 \mathrm{M}$ $\mathrm{NaOH}(1: 1 \mathrm{v} / \mathrm{v})$. These were stored protected from light at $4^{\circ} \mathrm{C}$, since under these storage conditions they were stable. All HPLC experiments were carried out with a Shimadzu LC-20AD liquid chromatograph system (Kyoto, Japan) associated with an SPD-M20A photodiode array detector, with a column oven (CTO-20A). The system was controlled by the LC-Solution Single software. The analyses were performed with a Shim-Pack CLCODS C18 column $(250 \mathrm{~mm}$ x $4.6 \mathrm{~mm}$ i.d., $5 \mu \mathrm{m}$ particle size, Shimadzu). A Rheodyne 7125i sample injector valve with $20 \mu \mathrm{L}$ filling loop (Berkeley, CA, USA) was used. The mobile phase consisted of a mixture of solvent $\mathrm{A}$ (water, $1 \%$ acetic acid, $\mathrm{pH}$ $3.9)$ and solvent $\mathrm{B}(90 \% \mathrm{MeOH}, 10 \%$ acetonitrile), starting from B-A, 65 to $35 \%$. The column oven temperature was set at $25^{\circ} \mathrm{C}$ and the mobile phase was pumped at a flow rate of $1 \mathrm{~mL} / \mathrm{min}$, and the eluent was monitored at $254 \mathrm{~nm}$.

Aliquots of the same hemolymph samples from the first experiment were vortexed and centrifuged for $10 \mathrm{~min}$ at $3500 \mathrm{rpm}$. The supernatant was removed and the undissolved particles were removed by filtration using $45 \mu \mathrm{m}$ membrane filters. Aliquots of $20 \mu \mathrm{L}$ were used for the chromatographic analysis.

\section{SHORT-TERM RADIOIODIDE UPTAKE: In vivo NIS FUNCTION}

It was previously shown that the measurement of radioiodide uptake $15 \mathrm{~min}$ after ${ }^{125} \mathrm{I}-\mathrm{NaI}$ administration (short-term iodide uptake) reflects iodide transport through the sodium-iodide symporter (NIS) without influence of in vivo thyroid iodine organification activity (Ferreira et al. 2005). Thus, to evaluate the in vivo NIS function in snails under basal conditions $(n=6)$ using digestive gland (DG) and cerebral ganglia (CG) material and measure the radioiodine uptake, $\mathrm{Na}-{ }^{125} \mathrm{I}$ (3700 Bq, Amersham, Buckinghamshire, England) was administered in the medial region of the cephalopodal mass with a hypodermic syringe $15 \mathrm{~min}$ before decapitation. In the thyroid, iodine organification is catalyzed by TPO and consists of binding of iodine to tyrosil residues in thyroglobulin, an essential step of TH biosynthesis. The radioactivity of the tissues was measured using a gamma counter (LKB) and expressed as percentage of total ${ }^{125} \mathrm{I}$ injected per $\mathrm{mg}$ of DG 
or CG. After this, six different snails received a solution of potassium perchlorate $(0.40 \mathrm{mg} / 100 \mu \mathrm{L})$, an inhibitor of NIS activity, two minutes before $\mathrm{Na}-{ }^{125}$ I administration, after which the radioactivity was measured as above. As there is no published information about pharmacological approaches to thyroid function in snails, the $\mathrm{Na}-{ }^{125} \mathrm{I}$ and $\mathrm{KClO}_{4}$ administrations were based in values used for rats (Ferreira et al. 2005).

\section{STATISTICAL ANALYSIS}

The results are expressed as mean \pm standard error. The unpaired Student t-test was used to compare two groups. Nonlinear regression was applied to analyze the relation between $\mathrm{T} 4$ concentration and body weight and body size of the snails. The statistical analyses were performed using GraphPad Prism $^{\circledR} 5$ (Graphpad Software, Inc., San Diego, USA). For all comparisons, the differences between means were considered statistically significant for $\mathrm{P}<0.05$.

\section{RESULTS}

As observed in Figure 1, only $\mathrm{T}_{4}$ was found in the $A$. fulica hemolymph by RIA analysis $(3.49 \pm$ $0.55 \mu \mathrm{g} / \mathrm{dL}$ ). After four weeks of starvation, there was a significant decrease of $\mathrm{T}_{4}$ concentrations $(2.27 \pm 0.16$ vs. $3.49 \pm 0.55 \mu \mathrm{g} / \mathrm{dL}, \mathrm{P}<0.05)$ in A. fulica hemolymph in relation to the control. Similarly, the $\mathrm{T}_{4}$ concentrations decreased after hemolymph deproteinization both in non-starved $(0.63 \pm 0.08$ vs. $3.49 \pm 0.55 \mu \mathrm{g} / \mathrm{dL}, \mathrm{P}<0.0001)$ and starved groups $(0.69 \pm 0.11$ vs. $2.27 \pm 0.16 \mu \mathrm{g} /$ $\mathrm{dL}, \mathrm{P}<0.0001$ ) when compared to their respective controls. Also, there was a weak relation between $\mathrm{T}_{4}$ levels and body size and body weight $\left(\mathrm{r}^{2}=0.53\right.$ and 0.26 , respectively) (Fig. 2a and b).

Nevertheless, qualitative HPLC analysis showed that $\mathrm{T}_{2}, \mathrm{~T}_{3}$ and $\mathrm{T}_{4}$ were present in $A$. fulica hemolymph but not reverse $\mathrm{T}_{3}$ (Fig. 3). This analysis was confirmed by the similar retention time between the standards and samples, as well as the ultraviolet absorbance curve designed for the hormones (Fig. 4). The profiles obtained here suggest that THs have low concentrations in this snail's hemolymph.

In an attempt to identify the putative production site of these hormones, NIS activity was measured. For this assay, CG and DG were collected because earlier studies have shown that these tissues are able to produce several hormones (Davidson et al. 1971, Geraerts 1976, Roubos et al. 1980, Jong-Brink et al. 1981). The results showed that CG seems to take up more ${ }^{125}$ I than DG $(194.11 \pm 40.99$ and $68.11 \pm$ $16.17{ }^{125}$ I uptake/mg tissue, $\mathrm{P}<0.05$, respectively). However, these results may be deceiving because: i) these animals have an open circulatory system; and ii) the protocol was conducted in vivo. So, $\mathrm{KClO}_{4}$, an inhibitor of NIS activity, was used before ${ }^{125} \mathrm{I}-\mathrm{NaI}$ administration. Curiously, $\mathrm{KClO}_{4}$ did not impair iodide uptake (Fig. 5).

\section{DISCUSSION}

Only $\mathrm{T}_{4}$ was found in A. fulica hemolymph by RIA analysis, and its levels declined after both starvation and hemolymph deproteinization. The decrease of $\mathrm{T}_{4}$ concentrations is a well-established condition observed during starvation that is secondary to decrease of the thyrotropin-releasing hormone (TRH) and thyroid-stimulating hormone (TSH) secretion (Krotkiewski 2000). Also, since THs are known to increase energy metabolism and thermogenesis (Ribeiro et al. 2001), it is reasonable to expect the animals subjected to fasting to present a lower level of THs, in line with the smaller energy input during fasting (adaptive phenomenon). On the other hand, it was previously demonstrated that echinoids can also obtain THs from food (algae) (see Heyland and Moroz 2005), suggesting that the decrease of THs after starvation could also be associated with the lower support of exogenous THs. However, to our knowledge there 


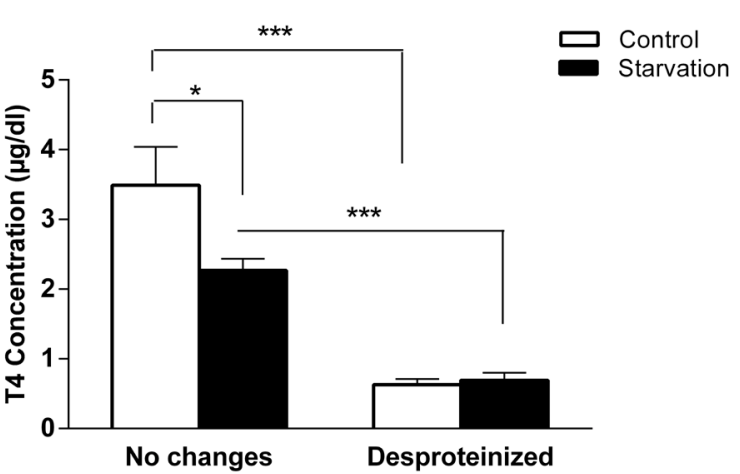

Figure 1 - Thyroxin $\left(\mathrm{T}_{4}\right)$ concentration in hemolymph of Achatina fulica, expressed in $\mu \mathrm{g} / \mathrm{dL}$, under basal and starvation conditions as well as hemolymph desproteinization. The hemolymph samples were obtained from 10 snails per group, but when necessary the samples were pooled. * Indicates significant difference between groups $(\mathrm{P}<0.05)$. *** Indicates significant difference between groups $(\mathrm{P}<0.0001)$.
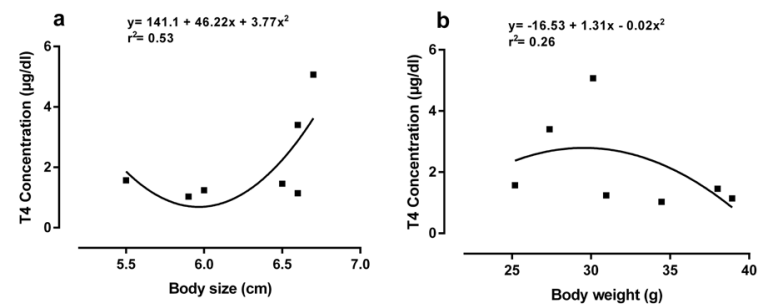

Figure 2 - Relation between the thyroxin $\left(\mathrm{T}_{4}\right)$ concentration, expressed in $\mu \mathrm{g} / \mathrm{dL}$, in hemolymph of Achatina fulica $(\mathrm{n}=7)$ and its body size (a), expressed in centimeters ( $\mathrm{cm}$ ) and body weight (b), expressed in grams (g).

is no information regarding TH synthesis in lettuce plants (used as food in our experiments). Besides this, the presence/synthesis of THs in different species of mollusks and of TSH hormones in the pulmonate gastropod, L. stagnalis (Tensen et al. 1994), indicate that $A$. fulica snails are also able to produce endogenous THs.

In the present study, the $\mathrm{T}_{4}$ concentrations varied greatly among animals. Since we had no data on age, we tried to correlate the biomass of the mollusks with the $\mathrm{T}_{4}$ concentrations. However, no significant correlation was detected.

The decrease of $\mathrm{T}_{4}$ concentrations after hemolymph deproteinization is consistent with the fact that THs bind to plasmatic proteins, mainly
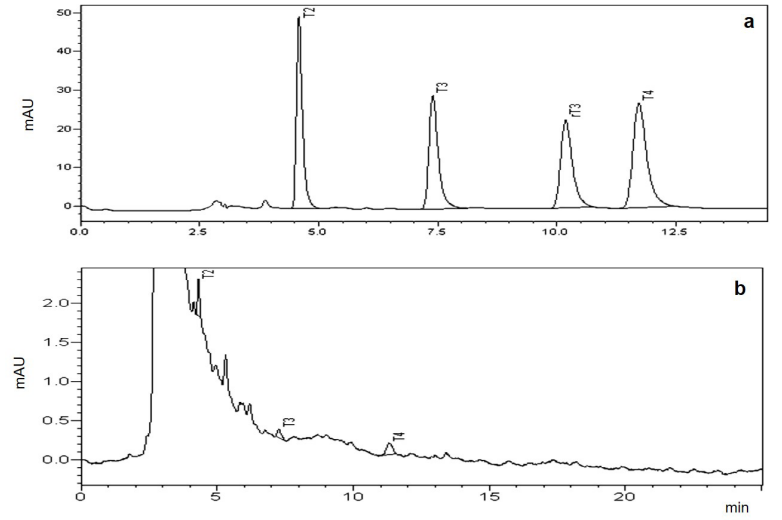

Figure 3 - Indicative chromatograms of spiked biological samples: (a) standard iodoamino acids and (b) hemolymph samples from Achatina fulica snails on a Shim-Pack CLCODS C18 column $(250 \mathrm{~mm} \times 4.6 \mathrm{~mm}$ i.d., $5 \mu \mathrm{m}$ particle size, Shimadzu). The mobile phase consisted of a mixture of solvent A (water, 1\% acetic acid, pH 3.9) and solvent $\mathrm{B}(90 \% \mathrm{MeOH}$, $10 \%$ acetonitrile), starting from B - A, 65 to $35 \%$. The column oven temperature was set at $25^{\circ} \mathrm{C}$ and the mobile phase was pumped at a flow-rate of $1 \mathrm{~mL} / \mathrm{min}$, and the eluent was monitored at 254nm. Peaks: $\left(\mathrm{T}_{2}\right)$ 3,5-diiodo-1-thyronine (4.58 vs. 4.30min, respectively), ( $\left.\mathrm{T}_{3}\right)$ 3,3',5-triiodo-1-thyronine (7.38 vs. 7.24min), $\left(\mathrm{rT}_{3}\right)$ reverse 3,3',5'-triiodo-L-thyronine (10.17 $\min$ ), and $\left(\mathrm{T}_{4}\right)$ 3,3',5,5'-Tetra-iodo-1-thyronine 1-thyroxine (11.71 vs. $11.30 \mathrm{~min})$. On the y-axis, the peak area is expressed as absorbance units (mAU).

thyroxin-binding globulin (TBG), in vertebrates (Yen 2001), although more elaborate experiments are needed to elucidate this issue. So, the deproteinization process must have depleted the hormone binding proteins that probably exist in the hemolymph of $A$. fulica snails. Moreover, hormonebinding proteins have previously been detected in mollusks (D'Aniello et al. 1996, Bogoeva and Russev 2008).

In addition, HPLC analysis showed the presence of $\mathrm{T}_{2}, \mathrm{~T}_{3}$ and $\mathrm{T}_{4}$, but not $\mathrm{rT}_{3}$. These results confirm the presence of THs in A. fulica snails. However, the evaluation of the chromatographic profile obtained suggests these hormones have low concentration in the A. fulica hemolymph. A study by Tensen et al. (1994) detected TSH receptors in the freshwater gastropod L. stagnalis, which supports our idea of a functional activity of THs 

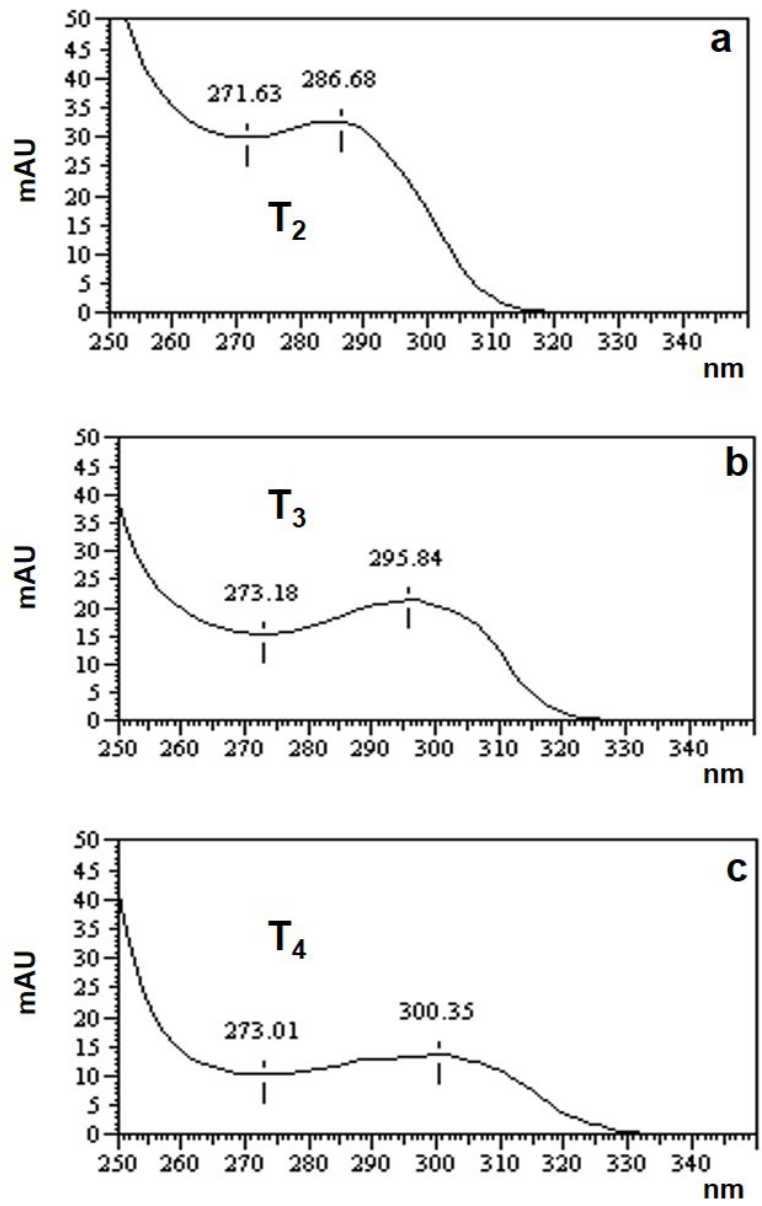

Figure 4 - Comparison of standard iodoamino acids spectra, wavelength of 250 to $350 \mathrm{~nm}$, obtained using HPLC- PDA. (a) $\mathrm{T}_{2}$, (b) $\mathrm{T}_{3}$, and (c) $\mathrm{T}_{4}$. These data are similar to those reported by de la Vieja et al. (1997). On the y-axis, the ultraviolet spectrum is expressed as absorbance units (mAU).

in mollusks. Due to the phylogenetic proximity of these two species, it is possible suggest that $A$. fulica snails have a functional thyroid system. The decrease of $\mathrm{T}_{4}$ levels after starvation strengthens this idea.

To date we have no explanation for the fact that iodide uptake activity was not blocked after $\mathrm{KClO}_{4}$ treatment. Similar results were obtained by Heyland et al. (2006). These authors demonstrated that $\mathrm{KClO}_{4}$ does not change the uptake of iodide in echinoderms, suggesting that the results found were due to differences in iodine transport between the mammalian thyroid gland and

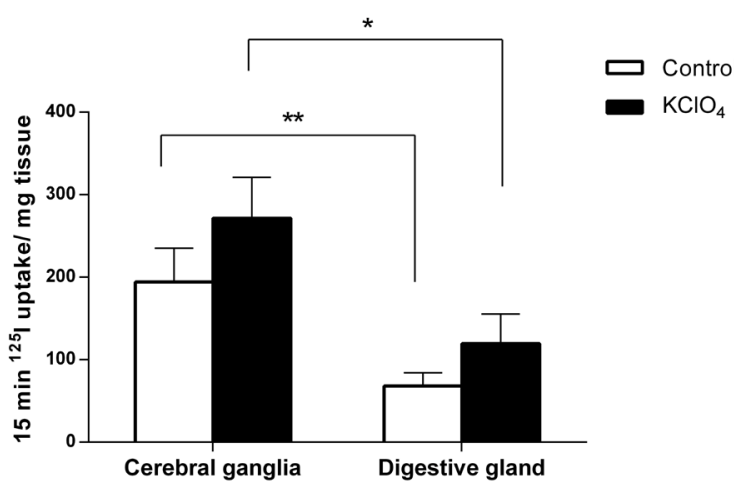

Figure 5 - Short-term radioiodide uptake study performed in Achatina fulica snails with $(\mathrm{n}=6)$ and without $\mathrm{KClO}_{4}$ treatment $(n=6)$. The tissues of both cerebral ganglia $(C G)$ and digestive gland (DG) were removed, weighed and the radioactivity was measured using a gamma counter and expressed as $15 \mathrm{~min}$ ${ }^{125}$ I uptake/mg tissue. Data are expressed as mean \pm SEM. * Indicates significant difference between groups $(\mathrm{P}<0.05)$. ** Indicates significant difference between groups $(\mathrm{P}<0.001)$.

echinoderm cells. Moreover, Miller and Heyland (2013) demonstrated that iodine accumulation in the sea urchin Strongylocentrotus purpuratus is independent of NIS transport and seems to be mediated by peroxide-dependent diffusion. In turn, it is possible that in A. fulica the iodine uptake occurs by epithelial diffusion. Considering that A. fulica does not have follicular thyroid tissue or its homologous endostyle, our results suggest that CG could be able of synthetize THs in A. fulica since this neural tissue showed greater uptake of iodine than DG, which is consistent with the results of previous studies showing that the CG has the ability to secrete various hormones (Geraerts 1976, Roubos et al. 1980).

The identification of THs in snails is extremely important because it suggests the presence of a new pathway that can regulate the metabolism of this invertebrate group. This sheds more light on the spread, survival and reproduction of this species of snail. Moreover, recently Wu et al. (2007) demonstrated the presence of $\mathrm{TH}$ receptors in the genome of Schistosoma mansoni, a parasite distributed worldwide that infests snails and 
vertebrates during its complex life cycle. Saule et al. (2002), studying the effects of murine infection with $S$. mansoni, found that rats treated with thyroxine had an increase in the number and development of giant worms, whereas a diet deficient in iodine reduced the maturation of the parasite and number of eggs laid, and caused liver disease. The idea that neurohumoral systems of definitive or even intermediate hosts play a key role in infection processes of parasites has grown enormously. However, in relation to THs, the importance of the humoral loop is poorly understood in these animals. Taken together, these results provide strong evidence that THs are highly conserved during phylogenetic evolution and may have an important role in species conservation.

In conclusion, the present study demonstrates for the first time the presence of THs in the snail A. fulica, a terrestrial gastropod. We observed the presence of $\mathrm{T}_{4}, \mathrm{~T}_{3}$ and $\mathrm{T}_{2}$ in the hemolymph of these animals through HPLC analysis, although these were present in low concentrations. The decrease in $\mathrm{T}_{4}$ levels after fasting and hemolymph deproteinization indicates similarities with vertebrates, and suggests its participation in the metabolic control of this snail, but the physiological role of this hormone remains elusive.

\section{ACKNOWLEDGMENTS}

This study was supported in part by Conselho Nacional de Desenvolvimento Científico e Tecnológico (CNPq), Fundação Carlos Chagas Filho de Amparo à Pesquisa do Estado do Rio de Janeiro (FAPERJ), and Coordenação de Aperfeiçoamento de Pessoal de Nível Superior (CAPES).

\section{REFERENCES}

ALEXANDER NM AND NISHIMOTO M. 1979. Rapid analysis for iodotyrosines and iodothyronines and thyroglobulin by reversed-phase chromatography. Clin Chem 25: 1757-1760.
BOGOEVA VP AND RUSSEV GC. 2008. Fluorescence study of steroid hormone binding activity of Helix pomatia agglutinin. Steroids 73: 1060-1065.

D'ANIELLO A, DI COSMO A, DI CRISTO C, ASSISI L, BOTTE V AND DI FIORI MM. 1996. Occurrence of sex steroid hormones and their binding proteins in Octopus vulgaris Lam. Biochem Biophys Res Commun 227: 782788.

DAVIDSON JK, FALKMER S, MEHROTRA BK AND WILSON S. 1971. Insulin assays and light microscopical studies of digestive organs in protostomian and deuterostomian species and in coelenterates. Gen Comp Endocrinol 17: 388-401.

DE LA VIEJA A, CALERO M, SANTISTEBAN P AND LAMAS L. 1997. Identification and quantitation of iodotyrosines and iodothyronines in proteins using highperformance liquid chromatography by photodiode-array ultraviolet-visible detection, J Chromatogr B Biomed Sci Appl 688: 143-149.

FERREIRA AC, LIMA LP, ARAÚJO RL, MULLER G, ROCHA RP, ROSENTHAL D AND CARVALHO DP. 2005. Rapid regulation of the thyroid sodium-iodide symporter (NIS) activity by thyrotropin and iodine. J Endocrinol 184: 69-77.

GERAERTS WPM. 1976. The role of the Lateral Lobes in the control of growth and reproduction in the hermaphrodite freshwater snail Lymnaea stagnalis. Gen Comp Endocrinol 29: 97-108.

GIKA HG, SAMANIDOU VF AND PAPADOYANNIS IN. 2005. Development of a validated HPLC method for the determination of iodotyrosines and iodothyronines in pharmaceuticals and biological samples using solid phase extraction. J Chromatogr B: Anal Technol Biomed Life Sci 814: 163-172.

GOMOT A, GOMOT L, MARCHAND CR, COLARD C AND BRIDE J. 1992. Immunocytochemical localization of insulin-related peptide(s) in the central nervous system of the snail Helix aspersa Müller: involvement in growth control. Cell Mol Neurobiol 12: 21-32.

GONZALEZ GC, ROGER I, GONZALEZ E, MARTINEZPADRON M, MOORE GJ AND LUKOWIAK K. 1995. Angiotensinogen-like epitopes are present in the CNS of Aplysia California and co-localize with urotensin Iand urotensin II-like immunoreactivities in the cerebral ganglia. Neuroreport 15: 541-544.

GOODING MP AND LEBLANC GA. 2004. Seasonal variation in the regulation of testosterone levels in the eastern mud snail (Ilyanassa obsoleta). Invert Biol 123: 237- 243.

GUPTA BB AND CHAKRABARTY P. 1990. Effects of thyroidal, gonadal and adrenal hormones on tissue respiration of streaked frog, Rana limnocharis, at low temperature. Indian J Exp Biol 28: 23-26. 
HABER RS, ISMAIL-BEIGI F AND LOEB JN. 1988. Time course of $\mathrm{Na}, \mathrm{K}$ transport and other metabolic responses to thyroid hormone in clone 9 cells. Endocrinology 123 : 238-247.

HEYLAND A AND MOROZ LL. 2005. Cross-kingdom hormonal signaling: an insight from thyroid hormone functions in marine larvae. J Exp Biol 208 (Pt 23): 43554361.

HEYLAND A, PRICE DA, BODNAROVA M AND MOROZ LL. 2006. Thyroid hormone metabolism and thyroid peroxidase function in two nonchordate animals. J Exp Zool B Mol Dev Evol B 306: 551-566.

HUANG W, XU F, QU T, ZHANG R, LI L, QUE H AND ZHANG G. 2015. Identification of Thyroid hormones and functional characterization of thyroid hormone receptor in the Pacific Oyster Crassostrea gigas provide insight into evolution of the thyroid hormone system. PLoS One 10: e0144991.

JONG-BRINK M, SCHOT LPC, SCHOENMAKERS HJN AND BERGAMIN-SASSEN MJM. 1981. A biochemical and quantitative electron microscope study on steroidogenesis in ovotestis and digestive gland of the pulmonate snail Lymnaea stagnalis. Gen Comp Endocrinol 45: 30-38.

KROTKIEWSKI M. 2000. Thyroid hormones and treatment of obesity. Int J Obes 24: 116-119.

LARSEN PR, DAVIES TF AND HAY ID. 1998. The thyroid gland. In: Wilson JD, Foster DW, Kronemberg HM and Larsen PR. Williams Textbook of Endocrinology, $9^{\text {th }}$ ed., W.B. Saunders Company, Philadelphia.

MILLER AE AND HEYLAND A. 2013. Iodine accumulation in sea urchin larvae is dependent on peroxide. J Exp Biol 1: $915-926$.

NELSON N. 1944. A photometric adaptation of the Somogyi method for the determination of glucose. J Biol Chem 153: 375-380.
RIBEIRO MO, CARVALHO SD, SCHULTZ JJ, CHIELLINI G, SCANLAN TS, BIANCO AC AND BRENT GA. 2001. Thyroid hormone--sympathetic interaction and adaptive thermogenesis are thyroid hormone receptor isoform specific. J Clin Invest 108: 97-105.

ROUBOS EW, GERAERTS WPM, BOERRIGTER GH AND VAN KAMPEN GPJ. 1980. Control of the activities of the neurosecretory light green and Caudo-Dorsal Cells and of the endocrine dorsal bodies by the lateral lobes in the freshwater snail Lymnaea stagnalis (L.). Gen Comp Endocrinol 40: 446-454.

RUDOLPH PH AND BAILEY JB. 1985. Copulation as females and use of allosperm in the freshwater snail genus Bulinus (Gastropoda:Planorbidae). J Mollus Stud 51: 267275.

SAULE P, ADRIAENSSENS E, DELACRE M, CHASSANDE O, BOSSU M, AURIAULT C AND WOLOWCZUK I. 2002. Early variations of host thyroxine and interleukin-7 favor Schistosoma mansoni development. J Parasitol 88: 849-855.

TENSEN CP, VAN KASTEREN ER, PLANTA RJ, COX KJ, BURKE JF, VAN HEERIKHUIZEN H AND VREUGDENHIL E. 1994. A G protein coupled receptor with low-density lipoprotein-bindig motifs suggests a role for lipoproteins in G-linked signal transduction. Proc Natl Acad Sci USA 91: 4816-4820.

THIENGO SC, FARACO FA, SALGADO NC, COWIE RH AND FERNANDEZ MA. 2007. Rapid spread of an invasive snail in South America: the giant African snail, Achatina fulica, in Brazil. Biological Invasions 9: 693702.

WU W, NILES EG AND LOVERDE PT. 2007. Thyroid hormone receptor orthologues from invertebrate species with emphasis on Schistosoma mansoni. BMC Evol Biol 7: 150.

YEN PM. 2001. Physiological and molecular basis of thyroid hormone action. Physiol Rev 81: 1097- 1142. 